\title{
Ib Faurby
}

\section{Ruslands væbnede styrker i krise og krig}

\begin{abstract}
President Vladimir Putin onsker at styrke statsmagten. Et centralt element heri er en effektivisering af de vebnede styrker. Putin har imidlertid overtaget et forsar $i$ krise og praget af manglende reformer. Ikke mindst de to russisk-tjetjenske krige. 1994-1996 og siden 1999. har pat den mest dramatiske máde vist de store problemer. der prager de russiske vabnede styrker.
\end{abstract}

Lige siden Sovjetunionens opløsning og Den Russiske Føderations indtreden på den internationale scene som en selvstendig stat har det russiske samfund befundet sig i en turbulent omstillingsproces. Det gælder i høj grad også de væbnede styrker. I denne sammenhæng bruges "forsvaret" og "de vabnede styrker" synonymt om de styrker, der hører under det russiske forsvarsministerium. De øvrige væbnede enheder under andre ministerier og tjenester behandles ikke i denne artikel.

Problemstillingen er den militære side af Ruslands systemskifte fra diktatur til demokratiske tilstande, som analyseres kronologisk. Indledningen uddyber baggrunden og perspektiverne i denne proces. Dernæst belyses de russiske aktørers eget syn på udfordringerne og de halvhjertede reformer, det i første omgang førte til. Så drøftes den teknologiske og menneskelige faktor, og som en casestudie i militærets krisestyring gennemgăs forløbet af første og anden Tjetjenienkrig. Af hensyn til kronologien er der et mellemliggende afsnit om det senere reformforløb, hvorved drøftelsen af anden Tjetjenien-krig bliver en vurdering af reformernes effekt. Den afsluttende del om Putins forsvarspolitik påpeger, at der er taget visse skridt til en militarisering af det russiske samfund.

Omstillingen fra den sovjetiske supermagts gigantiske militærapparat til et forsvar, som Rusland har råd til, og som svarer til landets reelle sikkerhedspolitiske behov, har varet vanskelig og kaotisk. De store politiske, økonomiske og sociale problemer, der har preget Rusland i 1990'erne, har sat sine spor i forsvaret $o g$ besværliggjort de nødvendige reformer. Ingen steder er det kommet tydeligere til udtryk end i de to russisk-tjetjenske krige.

Efter det mislykkede forsøg på at oprette et falles forsvar for Sammenslutningen af Uafhængige Stater ( $\mathrm{SNG}$ ), besluttede Rusland i maj 1992 at oprette sit eget forsvar. Ruslands sikkerhedspolitiske situation var imidlertid en ganske anden, end Sovjetunionens havde været. Warszawapagtens og Sovjetunionens opIøsning æendrede fundamentalt den geo-strategiske situation i Europa. Dertil kom, at de centralasiatiske og transkaukasiske republikkers selvstændighed betød, at Rusland mod syd havde mistet sit strategiske forterran i konfliktfyldte områder.

Derfor var der behov for grundlaggende andringer af forsvaret. Der mătte enten foretages betydelige nyinvesteringer eller drastiske nedskaringer. Men på grund af samfundets generelle økonomiske problemer var det ikke muligt at investere de beløb $i$ en rekonstruktion af de vabnede styrker, som forsvarets le- 


\title{
Ib Faurby
}

\section{Ruslands væbnede styrker i krise og krig}

\begin{abstract}
President Vladimir Putin onsker at styrke statsmagten. Et centralt element heri er en effektivisering af de vebnede styrker. Putin har imidlertid overtaget et forsar $i$ krise og praget af manglende reformer. Ikke mindst de to russisk-tjetjenske krige. 1994-1996 og siden 1999. har pat den mest dramatiske máde vist de store problemer. der prager de russiske vabnede styrker.
\end{abstract}

Lige siden Sovjetunionens opløsning og Den Russiske Føderations indtreden på den internationale scene som en selvstendig stat har det russiske samfund befundet sig i en turbulent omstillingsproces. Det gælder i høj grad også de væbnede styrker. I denne sammenhæng bruges "forsvaret" og "de vabnede styrker" synonymt om de styrker, der hører under det russiske forsvarsministerium. De øvrige væbnede enheder under andre ministerier og tjenester behandles ikke i denne artikel.

Problemstillingen er den militære side af Ruslands systemskifte fra diktatur til demokratiske tilstande, som analyseres kronologisk. Indledningen uddyber baggrunden og perspektiverne i denne proces. Dernæst belyses de russiske aktørers eget syn på udfordringerne og de halvhjertede reformer, det i første omgang førte til. Så drøftes den teknologiske og menneskelige faktor, og som en casestudie i militærets krisestyring gennemgăs forløbet af første og anden Tjetjenienkrig. Af hensyn til kronologien er der et mellemliggende afsnit om det senere reformforløb, hvorved drøftelsen af anden Tjetjenien-krig bliver en vurdering af reformernes effekt. Den afsluttende del om Putins forsvarspolitik påpeger, at der er taget visse skridt til en militarisering af det russiske samfund.

Omstillingen fra den sovjetiske supermagts gigantiske militærapparat til et forsvar, som Rusland har råd til, og som svarer til landets reelle sikkerhedspolitiske behov, har varet vanskelig og kaotisk. De store politiske, økonomiske og sociale problemer, der har preget Rusland i 1990'erne, har sat sine spor i forsvaret $o g$ besværliggjort de nødvendige reformer. Ingen steder er det kommet tydeligere til udtryk end i de to russisk-tjetjenske krige.

Efter det mislykkede forsøg på at oprette et falles forsvar for Sammenslutningen af Uafhængige Stater ( $\mathrm{SNG}$ ), besluttede Rusland i maj 1992 at oprette sit eget forsvar. Ruslands sikkerhedspolitiske situation var imidlertid en ganske anden, end Sovjetunionens havde været. Warszawapagtens og Sovjetunionens opIøsning æendrede fundamentalt den geo-strategiske situation i Europa. Dertil kom, at de centralasiatiske og transkaukasiske republikkers selvstændighed betød, at Rusland mod syd havde mistet sit strategiske forterran i konfliktfyldte områder.

Derfor var der behov for grundlaggende andringer af forsvaret. Der mătte enten foretages betydelige nyinvesteringer eller drastiske nedskaringer. Men på grund af samfundets generelle økonomiske problemer var det ikke muligt at investere de beløb $i$ en rekonstruktion af de vabnede styrker, som forsvarets le- 
delse fandt nødvendig. Problemet blev yderligere forstærket af konservative holdninger $i$ den militære ledelse og rivalisering mellem værn og våbenarter. Resultatet blev en styrkestruktur, der ikke kunne finansieres eller - om man vil - manglende sammenhæng mellem mål og midler.

\section{Ideologi og doktrin}

Det grundlæggende spørgsmål var, hvad det var, der skulle forsvares. Den Russiske Føderation blev af de færreste betragtet som et "naturligt" land. Der havde aldrig eksisteret noget "historisk" Rusland med de grænser, føderationen fik. Og hvis formålet var at forsvare russerne, så var problemet, at ikke alene boede der et betydeligt antal ikke-russere i Den Russiske Føderation, men også omkring 25 millioner russere uden for føderationen i de tidligere sovjetrepublikker. Faktisk fortsatte russiske militære styrker med at spille en ganske problematisk rolle i flere tidligere sovjetrepublikker - ikke mindst i "udbryderrepublikkerne" Transdniestrien (Moldova) og Abkhasien (Georgien - se Mette Skaks artikel i dette Politica).

Tidligere havde der ikke været tvivl om, at det var Sovjetunionens Kommunistiske Parti (SUKP), der havde den reelle magt og ifølge forfatningen ligefrem den "ledende rolle" i samfundet. Inden for forsvaret havde partiet en politisk kommandostruktur parallelt med den militære, og hovedparten af officererne var partimedlemmer. Men med SUKP's opløsning aktualiseredes spørgsmålet om, hvem de væbnede styrker skulle adlyde. Præsidenten eller Den Øverste Sovjet? Det problem blev på dramatisk vis illustreret under opgøret mellem præsident Boris Jeltsin og Den Øverste Sovjet i september-oktober 1993, hvor begge parter forsøgte at inddrage forsvaret på sin side i magtkampen.

Under kommunismen havde der heller ikke været tvivl om, hvad der var statens og dermed også de væbnede styrkers idégrundlag. Men med kommunismens fald opstod der et ideologisk vakuum. Officielt var Rusland et demokrati, men hvad det ville sige, var bẳde i teori og praksis et uafklaret spørgsmål. Problemet med civil, politisk kontrol med de væbnede styrker forblev uløst, og for en del af officerskorpset kom russisk nationalisme til at tjene som det nye idégrundlag (Faurby, 1996).

Mere konkret var spørgsmålene, hvad der truede Ruslands sikkerhed, og hvorledes disse trusler skulle imødegås. Et første bud herpå kom med den militærdoktrin, som præsident Jeltsin underskrev den 2. november 1993. Ifølge denne eksisterede der stadig en risiko for både kernevåbenkrig og større konventionelle konflikter, men denne risiko var dog aftaget betydeligt. Den største umiddelbare fare for krig kom fra "sociale, territoriale, religiøse, nationalt-etniske og andre konflikter". Væbnede konflikter, der opstod på grund af "aggressiv nationalisme og religiøs intolerance udgør en særlig trussel", hed det i doktrinen.

Det blev derfor en væsentlig opgave for Ruslands væbnede styrker at medvirke til inddæmningen og løsningen af sådanne konflikter. Dertil kom, at forsvarets styrker også kunne bistå de interne sikkerhedsstyrker med opretholdelse af ro og orden. Det kunne være tilfældet, hvis nationalistiske eller separatistiske kræfter truede føderationens integritet og forfatningsmæssige orden, eller hvis 
der blev oprettet ulovlige vaebnede styrker pâ Den Russiske Foderations territorium. Endelig skulle forsvaret bistå med gransebevogtning. bekiempelse af narkotika- og vabensmugling samt assistere i katastrofesituationer.

Den to-ledede trusselsopfattelse bestående af både faren for en storkrig (om end den var aftaget) $\mathrm{og}$ faren for etnisk-nationale konflikter gav imidlertid planliegningsproblemer. For det var vidt forskellige krav, de to konflikttyper stillede til de vaebnede styrkers strategi, organisering. udrustning og uddannelse. Militierdoktrinen gav ikke nogen anvisning på, hvordan dette dilemma skulle loses.

Det russiske forsvar tillagde vedtagelsen af en militerdoktrin stor betydning. Det var for så vidt forstaeligt i betragtning af den uklarhed om forsvarets rolle og organisering, der var opstiet i kølvandet på Sovjetunionens opløsning. Doktrinen kom dog kun i meget begranset omfang til at opfylde behovet for klare. overordnede retningslinjer. Dokumentel var prieget af vage formuleringer, der åbnede mulighed for konkurrerende fortolkninger. Disse uklarheder var formentlig et udtryk for kompromiser mellem stæerkt afvigende opfattelser af, hvad der var det russiske forsvars hovedopgaver, og hvorledes disse skulle løses (Faurby, 1996; Nilsson, 1997).

\section{Reformen, der udeblev}

Selv om Rusland havde overtaget broderparten af det tidligere Sovjetunionens vabnede styrker, var det langt fra et sammenhængende og hensigtsmæssigt struktureret forsvar, landet stod med i foråret 1992. Rusland overtog de sovjetiske styrker, der befandt sig i Rusland, hvoraf en betydelig del var af lavere kvalitet, samt de styrker, der blev trukket tilbage fra andre områder - først og fremmest det østlige Tyskland, Baltikum og Transkaukasien.

Ikke mindst tabet af store og veludrustede styrker og militzere installationer i Ukraine betød, at det russiske forsvar fik en problematisk sammensæining og struktur. Den delvise tilbagetrækning fra Transkaukasien skabte også behov for gennemgribende andringer i Det Nordkaukasiske Militardistrikt, der skiftede karakter fra et indre og mindre betydningsfuldt militærdistrikt til et grænsedistrikt i et strategisk vigtigt område. Flere af de styrker, der blev trukket tilbage fra Tyskland og Baltikum blev placeret i Nordkaukasus.

Den politiske og militzere ledelse var klar over, at der var behov for en gennemgribende reform. Men ikke om hvordan eller hvor meget, den måtte koste. Det nyetablerede forsvarsministerium fremlagde i 1992 en syvarsplan i tre faser, der var blevet udarbejdet af Generalstaben $i$ stor hast. I den forste fase frem til udgangen af 1993 skulle der udarbejdes mere detaljerede reformplaner, mens man forhandlede med de øvrige tidligere sovjetrepublikker om delingen af Sovjetunionens militare ressourcer.

I fase to, dvs. indtil udgangen af 1995, skulle forsvaret reduceres fra Sovjetunionens 4.5 millioner mand i 1991 til 1.5 millioner. Harens kerne skulle udgores af mobile styrker til hurtig indsattelse i konfliktområder og underlagt en ny, selvstandig kommando. I den tredje fase, der skulle vare gennemfort år 2000 , skulle Luftforsvarsstyrkerne og De Strategiske Raketstyrker lægges sammen med Flyvevåbnet. Militardistrikterne skulle nedlagges og erstattes af fire til seks strate- 
giske kommandoer. Et hovedelement i reformplanen var indførelsen af hvervede ("professionelle") soldater, der i år 2000 skulle udgøre 50 pct. af mandskabsstyrken (Nilsson, 1997).

Disse reformplaner stødte imidlertid på økonomiske vanskeligheder og modstand blandt konservative officerer i den militære ledelse. Præsident Jeltsin fandt tilsyneladende ikke spørgsmålet af tilstrækkelig betydning til, at han for alvor satte sin personlige autoritet bag reformplanerne, og forsvarsminister Pavel Gratjov havde hverken den intellektuelle kapacitet eller den politiske styrke til at sikre deres gennemførelse. Så selv om den nye militærdoktrin lagde stor vægt på faren for etnisk-nationale konflikter og sanktionerede anvendelsen af Forsvarsministeriets styrker i interne konflikter, førte doktrinen ikke til gennemgribende andringer i styrkernes organisering og uddannelse med henblik på sådanne konflikter.

\section{Materiel, moral og motivation}

Sovjetunionen havde brugt enorme ressourcer på sine væbnede styrker. De fleste forskere er i dag enige om, at det drejede sig om mellem $20 \mathrm{og} 25$ pct. af bruttonationalproduktet, og at dette var en medvirkende årsag til systemets sammenbrud. Det nye Rusland kom til verden i en økonomisk krise, der fortsatte op gennem 1990'erne. Bevillingerne til forsvaret faldt dramatisk sammenlignet med, hvad de havde været i sovjetperioden. De militære ledere modsatte sig imidlertid de reduktioner i styrkestrukturen, der skulle til for at skabe overensstemmelse mellem bevillinger og udgifter. Resultatet blev manglende vedligeholdelse af installationer og materiel, drastiske nedskæringer af uddannelse og træning, manglende lønudbetalinger og manglende evne til at sikre selv basale forsyninger, inkl. fødevarer, til tropperne.

For flådens vedkommende blev antallet af større overfladefartøjer og undervandsbåde halveret i tiåret fra 1987 til 1996. Disse tal kan tilmed være misvisende, da en stor del af de tilbageværende fartøjer er i en yderst ringe stand, og manglende brændstof og andre forsyninger har reduceret sejl- og øvelsestiden til et minimum. Den tidligere supermagt har i dag kun ét hangarskib og én helikopterkrydser (Holmberg, 2000). Kursk-katastrofen i august 2000, hvor Ruslands mest avancerede angrebsubåd forulykkede og gik ned med 112 mand ombord, var et dramatisk eksempel på flådens forfald. I flyvevåbnet er de fleste piloters flyvetimer faldet til 15-20 pr. år, hvor 150-180 timer pr. år er normen i mange NATOlande (Parchomenko, 1999).

Denne udvikling førte til en udbredt demoralisering blandt såvel officerer som menige. Officerskorpset oplevede en voldsom social deroute. Lønnen blev udhulet drastisk, og boligsituationen var katastrofal. Mange af de officerer og deres familier, der i sin tid blev trukket hjem fra Østeuropa og Baltikum, blev placeret i teltlejre og misligholdte kaserner. I 1998 var det godt 70 pct. af officererne, der ikke fik deres (i øvrigt meget beskedne) løn til tiden. Så sent som i 1999 mangler flere end 100.000 officerer ifølge officielle oplysninger stadig en bolig. Det er ikke overraskende, at meningsmălinger, der blev foretaget blandt officerer, var præget af utilfredshed og manglende tro på fremtiden (Parchomenko, 1999). 
Endnu varre stod det til bland de varnepligtige. Mange steder var deres situation slet og ret forfierdelig. En pensioneret oberst og militarsociolog sammenlignede i 1994 forholdene på mange kaserner med fortidens tvangsarbejdslejre (Ne-avisimaja Gazeta, 24.8.1994). Hvert år dor omkring 1.500 soldater af artsager, der ikke har med aktiv krigstjeneste at gore. Som i det øvrige samfund forte den moralske opløsning og de okonomisk-sociale problemer til en eksplosiv udvikling i kriminaliteten. I 1993 blev ca. 10.000 sager, omfattende alt fra mord til tyveri af vaben og ammunition. behandlet ved de militiere domstole. I Tjetjenien solgte officerer og menige våben til modparten.

Klimaet mellem officerer og menige og mellem de menige indbyrdes var ofte meget dårligt. Ikke mindst forholdet mellem soldater af forskellig etnisk oprindelse var problemfyldt. Mobning (dedovsitjina) af meget grov karakter var udbredt. I lobet af de forste ni måneder af 1997 blev der săledes registreret mere end 1.400 tilfalde af sarlig brutal behandling. I 1997 var der knap 500 tilfalde af selvmord blandt officerer og menige (Parchomenko, 1999: 102). Det var derfor ikke overraskende, at mange unge mand gjorde, hvad de kunne, for at slippe for militærtjeneste. Indtil en lovændring i 1995 var der gode muligheder for studerende for at blive fritaget. Mange fritages også på grund af dårligt helbred, men det er som regel de bedst uddannede, der er $\mathrm{i}$ stand til at sikre sig negative helbredsattester. Blandt de, der møder op, deserterer et betragteligt antal. I 1993, dvs. allerede inden den første krig i Tjetjenien, drejede det sig ifølge officielle oplysninger om $120 \mathrm{pr}$. uge. Både uddannelsesniveauet og helbredstilstanden blandt de, der indkaldes, siges at være væsentlig ringere end tidligere. $40 \mathrm{pct}$. af rekrutterne opfylder ikke de fysiske minimumskrav, og 25 pct. lider af kroniske sygdomme (Parchomenko, 1999: 100-101).

\section{Den kaotiske krig}

Intet demonstrerede mere tydeligt det russiske forsvars problemer end den russisk-tjetjenske krig 1994-96. Formålet med det følgende er ikke at give en udtømmende beskrivelse af denne konflikt, men udelukkende at illustrere, hvordan de generelle problemer gav sig konkrete udslag. For mere detaljerede analyser af denne såvel som den senere russisk-tjetjenske krig henvises til litteraturoversigten. Den første krig, som de russiske politiske og militære ledere havde forventet at afslutte i løbet af nogle fă uger, varede fra december 1994 til august 1996 og endte $\mathrm{i}$ et forsmædeligt nederlag for de russiske styrker og en accept af Tjetjeniens de facto selvstiendighed. Når den tidligere supermagts væbnede styrker var ude af stand til at opnå kontrol over Tjetjenien med sine kun ca. én million indbyggere og et areal, der kun er dobbelt så stort som Sjælland, skyldtes det flere forhold.

Den militire intervention var resultatet af de forudgående års forfejlede politik over for Tjetjenien og en hasarderet beslutning baseret pá manglende analyse af den politiske situation i Tjetjenien. Dertil kom en overdreven tro pả de varbnede styrkers effektivitet. Den overordnede ledelse af kamphandlingerne var praget af uenighed blandt de militare chefer og rivalisering mellem Forsvarsministeriets. Indenrigsministeriets og Sikkerhedstjenestens styrker (Baev, 
1996: 141-147). Ruslands økonomiske problemer kombineret med manglende vilje til at tilpasse styrkestrukturen betød, at størstedelen af hærens enheder var starkt underbemandede. Derfor mătte man operere med enheder, der var sammensat ad hoc, og som ikke tidligere havde øvet eller arbejdet sammen. Dertil kom, at det seneste hold færdiguddannede værnepligtige netop var blevet hjemsendt, da invasionen fandt sted. Flere enheder i Tjetjenien bestod derfor af rekrutter, der endnu ikke havde afsluttet deres militære grunduddannelse.

De økonomiske problemer afspejlede sig også i materiellet. Aleksandr Lebed, den tidligere general, der nu forsøgte sig som politiker, påstod, at kun en fjerdedel af de russiske kampvogne var klar til øjeblikkelig brug. Under fremrykningen mod Grosnij faldt to af hver ti kampvogne bagud for deres kolonner pà grund af mekaniske problemer. Både navigations- og văbensystemerne $\mathrm{i}$ hærens kamphelikoptere var så nedslidte, at det afgørende begrænsede deres operationsmuligheder.

Det erklærede formål med intervention var at "afvæbne illegale bander" og genoprette "den forfatningsmæssige orden". Hvordan dette konkret skulle gøres, synes ikke at være blevet afspejlet i egentlige politiske direktiver eller i klare forholdsordrer til styrkerne. Mange soldater og officerer troede, at de kom for at befri borgerne i Tjetjenien - tjetjenere săvel som russere - for et korrupt og diktatorisk styre. Derfor kom det bag på dem, at de blev mødt med indædt modstand ikke blot fra den tjetjenske præsident Dudajevs styrker, men også fra store dele af civilbefolkningen. Det skabte forvirring om operationens formål og om, hvordan man skulle forholde sig til såvel kombattanter som civile (Faurby, 1996).

Demoraliseringen af de russiske styrker påvirkede alle aspekter af krigen og kom ikke mindst til udtryk i de omfattende overgreb mod civilbefolkningen, der blev dokumenteret i mangfoldige rapporter fra såvel statslige som private internationale organisationer (Faurby og Magnusson, 2000). Den mest dramatiske afsløring af de russiske styrkers mangler kom under det forsøg på at indtage Grosnij, der blev indledt nytårsaften 1994. Af de fire grupperinger, der skulle rykke ind og mødes i centrum, var det kun den ene, der nåede frem. Den mistede 20 af sine 26 kampvogne og 102 af sine 120 pansrede mandskabsvogne. Dens chef og næsten 1000 officerer og menige omkom og 74 blev taget til fange af tjetjenerne (Faurby og Magnusson, 1999). Stormen på Grosnij var slået fejl. De russiske styrker måtte trække sig tilbage, omgruppere og få tilført yderligere forstærkninger fra militærdistrikter overalt i Rusland. Det var en overordentlig kritisk fase. Soldaternes moral var på nulpunktet og adskillige officerer tæt på lydighedsnægtelse.

Den russiske militære ledelse blev tvunget til at revurdere modparten og krigens karakter og til at ændre taktik. Derefter blev slaget om Grosnij en langstrakt kamp, hvor byen blev inddelt i sektorer, der én for én blev udsat for systematiske fly- og artilleriangreb, hvorefter infanteriet rykkede ind og erobrede kvarter for kvarter og hus for hus. Først den 6. marts var man nået så langt, at den russiske ledelse kunne erklære, at den havde kontrol over hele byen - hvad der dog siden skulle vise sig at være en sandhed med betydelige modifikationer.

I løbet af foråret 1995 erobrede de russiske styrker lavlandet og begyndte at trænge op i de sydlige bjerge. En dramatisk tjetjensk gidselaktion i den sydrussiske 
by Budjonnovsk forte imidlertid til en våbenhvile. Den gav tjetjenerne mulighed for en omgruppering. der betod en forbedring af deres stilling, da kamphandlingerne brod ud igen. Det blev nu en guerillakrig. hvor de russiske styrker aldrig opnàede fuld kontrol. end ikke med Grosnij. I august 1996 generobrede tjetjenerne hovedstaden. Efter forhandlinger mellem den nyindsatte sekretier for det russiske sikkerhedsråd, Aleksandr Lebed, og chefen for de tjetjenske styrker. Aslan Maskhadov, afsluttedes krigen med tilbagetrakning af alle russiske styrker og en aftale om, at forholdet mellem Tjetjenien og Den Russiske Foderation skulle afklares gennem forhandlinger inden 2001 (Faurby og Magnusson, 1999).

\section{Sergejevs plan}

Først i $1996 \mathrm{og}$ formentlig blandt andet på baggrund af problemerne under krigen i Tjetjenien begyndte president Jeltsin for alvor at interessere sig for reformer $\mathrm{i}$ forsvaret. Et forsvarsråd med presidenten som formand blev nedsat for at udstikke retningslinjer for reformarbejdet. Samtidig blev forsvarsminister Gratjov udskiftet med den hidtidige chef for Generalstabsakademiet, general Igor Rodionov. Han blev anset for at vare en betydelig militerteoretiker, og der var forventninger om, at der nu ville komme gang i reformerne. Det skete imidlertid ikke. Rodionov viste sig at have et ganske konservativt syn på forsvaret og stillede helt urealistiske økonomiske krav for at gennemføre reformer.

De manglende reformer kombineret med voksende kritik af Jeltsin i Dumaen var baggrunden for, at han i maj 1997 udstedte et dekret om forsvarsreformer, afskedigede Rodionov ( $\mathrm{g}$ chefen for Generalstaben) $\mathrm{og}$ i stedet udpegede chefen for De Strategiske Raketstyrker, general (senere marskal) Igor Sergejev, som forsvarsminister. Dermed syntes der langt om lange at være udsigt til egentlige reformer. Blandt hovedpunkterne i Sergejevs plan for udviklingen af styrkerne frem til 2005 var følgende:

- Forsvarsministeriets styrker skulle pr. 1. januar 1999 ikke overstige 1,2 millioner mand. Medregnet ubesatte stillinger betød det, at 120.000 mand af alle grader skulle afskediges.

- Sammenlagning af stabe, enheder og skoler.

- Nedlæggelse af 1/3 af stillingerne i den øverste ledelse.

- Bevare og modernisere de strategiske kernevåbenstyrker.

- Prioritering af kampenhederne og etablere en kerne af fuldt bemandede og udrustede divisioner og regimenter.

- Styrkelse af officersuddannelserne.

- Sociale garantier til officererne og deres familier.

Et vesentligt element i planen var en ændret balance mellem Forsvarsministeriets styrker og de mange paramilitiere organisationer under forskellige ministerier og tjenester. Siden president Jeltsin tiltradte, havde der fundet en ganske planlos vakst sted i antallet og størrelsen af sådanne organisationer, hvoraf hele 13 benyttede sig af værnepligtige, og som stadig i dag tæller godt tre millioner uniformerede personer. Ifølge Sergejevs plan skulle der gennemføres reduktioner i 
disse organisationer og i fremtiden kun indkaldes værnepligtige til Forsvaret, Indenrigsministeriets tropper, Grænsetropperne. Jernbanetropperne og FAPSI (Den Føderale Kommunikationstjeneste).

Videre skulle der i to etaper ske en sammenlægning af værnene, således at der i 2005 kun ville være tre værn: Hær, flåde samt rum- og flystyrker. Antallet af militærdistrikter skulle reduceres fra otte til seks. Militærdistrikterne, der hidtil primært havde været administrative enheder med ansvar for Forsvarsministeriets styrker, skulle omstruktureres og fungere som "operativt-strategiske kommandoer" med ansvar for alle militæere og paramilitære styrker inden for deres geografiske område, dvs. ikke blot Forsvarsministeriets styrker, men også Indenrigsministeriets styrker, grænsetropperne og civilforsvarstropperne (Nilsson, 1998 og 2000).

Sergejevs plan betød dog langt fra, at problemerne var løst. Som man kunne forvente, blev planen mødt med betydelig modstand i dele af forsvarets ledelse. Chefen for Generalstaben, general Anatolij Kvasnin, var således fundamentalt uenig i Sergejevs prioritering af kernevåbenstyrkerne på bekostning af de konventionelle styrker, hvad der da heller ikke forekom at være i overensstemmelse med det nye trusselsbillede. Også spørgsmålet om reformens finansiering gav anledning til uenighed. Sergejev mente (hvad der givetvis var det eneste politisk mulige), at reformen skulle gennemføres inden for rammerne af det eksisterende forsvarsbudget. Mange ledende officerer afviste imidlertid kategorisk, at dette kunne lade sig gøre.

\section{Den planlagte krig}

I januar 1997 blev den hidtidige chef for de tjetjenske styrker, Aslan Maskhadov, valgt til Tjetjeniens præsident ved et valg, som Organisationen for Sikkerhed og Samarbejde i Europa (OSCE) betegnede som "frit og fair". Republikken lå imidlertid i ruiner, og den lovede russiske hjælp til genopbygningen udeblev. Tårnhøj arbejdsløshed skabte grobund for kriminalitet, islamisk fundamentalisme og tiltagende politiske uoverensstemmelser. I august 1999 intervenerede en gruppe tjetjenere under ledelse af Sjamil Basajev i de interne uroligheder i naborepublikken Dagestan. (Basajev havde været en af de mest fremtrædende "feltkommandanter" under den første krig og var blevet nummer to ved præsidentvalget i 1997.) Russiske militære styrker i samarbejde med dagestansk milits slog opstanden ned og drev tjetjenerne tilbage. Selv om Basajevs indblanding fandt sted i strid med Maskhadovs politik, benyttede præsident Jeltsin og den nyudnævnte russiske ministerpræsident, Vladimir Putin, anledningen til at indlede en ny krig mod Tjetjenien. Det erklærede mål var at bekæmpe "international terrorisme", men det stod fra begyndelsen klart og kom efterhånden også til udtryk i officielle tilkendegivelser, at det egentlige formål var at tvinge den besværlige republik tilbage i Den Russiske Føderation (Magnusson og Faurby, 1999).

Der var tale om en langt mere velplanlagt operation end i 1994. De ovenfor omtalte, begyndende reformer af det russiske forsvar havde, selv om de langt fra var tilstrækkelige, haft en vis virkning. I Det Nordkaukasiske Militærdistrikt var man begyndt at integrere styrkerne fra alle de såkaldte magtministerier. Ved 
distriktets hovedkvarter havde man siden 1997 studeret den forste russisktjetjenske krig og lagt planer for en ny konfrontation. Man havde ogsa afholdt fielles ovelser for alle magtministerierne - dog hovedsagelig stabsovelser - baseret på "Tjetjenien-scenarier" (Main, 2000). Det var baggrunden for, at Rusland $\mathrm{i}$ september-oktober 1999 var i stand til på bemarkelsesvardig kort tid at indsatte en styrke pá ca. 90.000 mand i den nye konflikt. (I dette tal er hverken flystyrker eller en rekke støttefunktioner medregnet). I modsætning til tidligere bestod hovedparten af de styrker, der blev indsat i egentlige kampopgaver, af de ovenfor omtalte prioriterede enheder. Styrkerne var også bedre forsynet med uniformer. fodevarer, brendstof og ammunition.

Den nye krig blev indledt med omfattende bombardementer angiveligt af "terroristbaser", men var i realiteten en systematisk kampagne mod byer og landsbyer overalt i Tjetjenien, inkl. Grosnij. Derefter fulgte en intervention med store landstyrker i det nordlige Tjetjenien. Deres opgave blev angivet som etableringen af en "sikkerhedszone" nord for Terek-floden. Der blev også kastet miner og sat faldskarmsstyrker ind på gransen mellem Tjetjenien og Georgien for at afskare denne forbindelse ind og ud af republikken.

I midten af oktober rykkede de russiske styrker over Terek og begyndte at omringe Grosnij. Omkring 1. november indledtes, hvad der skulle blive et tre måneder langt angreb på den tjetjenske hovedstad. Belært af erfaringerne fra den første krig blev der ikke gjort noget forsøg på at tage Grosnij med storm. I stedet blev byen udsat for et uophørligt angreb fra fly, helikoptere og artilleri. Så vidt muligt forsøgte de russiske styrker at undgå direkte kontakt mand-til-mand med de tjetjenske forsvarere. Kampvogne og infanteri rykkede kun frem efter omfattende ildforberedelse, og når de stødte på modstand, trak de sig tilbage og tilkaldte yderligere artilleristøtte inden næste fremstød. Den 1. februar indledte tjetjenerne deres tilbagetrækning fra byen. Den tjetjenske hovedstyrke, der forsøgte at trække sig ud mod syd-vest, stødte på et russisk minefelt og led betydelige tab (Orr, 2000).

Derefter lykkedes det relativt hurtigt for russerne at satte sig på lavlandet og drive de tjetjenske styrker op i de sydlige bjerge. Her fortsatte kampene i de følgende måneder, ligesom det kom til jævnlige sammenstød mellem russiske $\mathrm{og}$ tjetjenske styrker rundt om i Tjetjenien. I januar 2001 erklarede prasident Putin, at der nu var en sådan grad af kontrol over området, at en del af hærstyrkerne kunne trækkes tilbage og hovedansvaret overdrages til Indenrigsministeriets og Sikkerhedstjenestens (FSB's) styrker. Der var dog intet, der tydede på, at konflikten var på vej til at finde en egentlig løsning.

Umiddelbart kunne det se ud som om, de begyndende reformer havde ført til større militær effektivitet. Restruktureringen af Det Nordkaukasiske Militærdistrikt havde - $\mathrm{i}$ hvert fald på det $\emptyset$ verste ledelsesniveau - forbedret planlægningen og koordineringen af de indsatte styrker. Det var også tydeligt, at kernen $\mathrm{i}$ den styrke, der blev indsat, var bedre organiseret og udrustet, end det havde været tilfældet under den første krig. Ligeledes kunne det se ud, som om det russiske forsvar havde lært af sine fejltagelser i den første krig og succesrigt bygget på denne erfaring $\mathrm{i}$ den anden krig. Det vil imidlertid være forhastet at 
konkludere, at den tilsyneladende større militære effektivitet var et resultat af en systematisk liereproces og succesrige reformer. En vigtig faktor er kildegrundlaget, som er langt mere spinkelt end tilfældet var for den første krigs vedkommende. Det skyldes de russiske militære myndigheders pressecensur, mediernes og den russiske offentligheds mindre kritiske holdning til den anden krig (Magnusson og Faurby, 2000).

En sammenligning af de to slag om Grosnij giver heller ikke umiddelbart grundlag for at vurdere, $\mathrm{i}$ hvor høj grad de russiske styrker reelt havde opnået en højere grad af militar professionalisme. Under den anden krig forsøgte man ikke at tage Grosnij med storm, men var på forhånd indstillet på en langvarig kamp. De russiske militære ledere var stadig klar over, at deres soldater ikke kunne måle sig med tjetjenerne i nærkamp inde $\mathrm{i}$ byen. Den afgørende forskel mellem de to erobringer af Grosnij var derfor, at russerne i anden omgang fra starten udnyttede deres overlegne ildkraft til en endnu mere systematisk ødelæggelse af byen uden hensyntagen til civilbefolkningen. Det seneste slag om Grosnij viser derfor ikke, at de russiske styrker er blevet bedre til bykamp. Byen blev ikke erobret; den blev jævnet med jorden.

Selv om de russiske styrker virkede mere velorganiserede under den anden $\mathrm{krig}$, så nåede der alligevel oplysninger ud til offentligheden om fejl, mangler og ineffektivitet - og fortsatte tab. I de første måneder af 2001 var de russiske tabstal formentlig på 15-20 soldater om ugen. Og trods den militære censur kunne internationale humanitære organisationer igen dokumentere de russiske styrkers alvorlige overgreb og brud på den humanitære folkeret, herunder mord, voldtægt, tortur og plyndringer (Faurby og Magnusson, 2000).

\section{Putins stærke stat}

I 2000 fik Rusland både et nyt nationalt sikkerhedskoncept og en ny militærdoktrin. Den nye militærdoktrin er et væsentlig mere gennemarbejdet dokument end doktrinen fra 1993. Som i den tidligere doktrin hedder det også i den nye, at faren for en storkrig, herunder en kernevåbenkrig, er reduceret, og at der er øget fare for nationale, etniske, religiøse og separatistiske konflikter samt grænseoverskridende kriminalitet. Blandt de eksterne trusler mod Rusland nævnes indblanding i Ruslands indre anliggender, konflikter tæt på Ruslands territorium og opbygningen af militære blokke og alliancer i strid med Ruslands interesser, herunder opstillingen af fremmede styrker tæt på Ruslands grænser. Samtidig er de internationale mekanismer, der skulle bidrage til international sikkerhed, blevet svækket, hedder det i en hentydning til NATOs Kosovo-operation uden FN-mandat (Møller, 2000a).

Til imødegåelse af disse trusler vil Rusland opretholde sin status som kernevåbenmagt, etablere et fælles forsvar med Hviderusland og styrke den kollektive sikkerhed blandt SNG-landene. Den øgede vægt på afskrækkelse med kernevåben skal ikke mindst ses i lyset af problemerne med nedskæring og omstrukturering af de konventionelle styrker. I det omfang doktrinen kommer ind på den konkrete organisering af de væbnede styrker, svarer den til forsvarsminister Sergejevs reformplan fra 1997. Sergejevs prioritering af kernevåbenstyrkerne 
var imidlertid, som nævnt. stodt på modstand fra generalstabschefen. general Kvasnin. Hvordan den nye forsvarsminister, Sergej Ivanov, vil stille sig til dette sporgsmål, vides endnu ikke.

Men Putin har klart tilkendegivet, at han onsker et starkt Rusland. Det betyder forst og fremmest en sterk centralmagt og en forbedret okonomi, men det betyder også effektive militere styrker. Dette er fremgået klart af mange udtalelser, blandt andet et mode med hojtstående officerer i januar 2001, hvor Putin påpegede sammenhiengen mellem en styrkelse af staten og moderniseringen af forsvaret. "Det er", sagde han, "nødvendigt at gøre hæren professionel, stærk, kompakt, disciplineret og mobil". De vabnede styrker må vaere i stand til at "udføre enhver tenkelig forsvarsopgave". Allerede i løbet af 2000 var der ifølge Putin truffet en rakke nøglebeslutninger, og man havde stået fast på "statens integritet for at sikre fred og orden, blandt andet i Nordkaukasus" (Krasnaja Zvezda, 19.01.2001).

Også $\mathrm{i}$ andre henseender er Putins vægt på forsvaret og hans egen tidligere tjeneste, FSB, kommet klart til udtryk. De fleste af de "generalguvernører", Putin har indsat til at overvåge republikker og regioner, kommer fra hæren eller FSB. Der er endvidere oprettet FSB-celler i det vabnede styrker og genindført før-militær uddannelse i skoler og uddannelsesinstitutioner (Møller, 2000b). Udnævnelsen i marts 2001 af Ivanov til "civil" forsvarsminister ændrer ikke ved dette billede $\mathrm{i}$ betragtning af hans fortid som generalløjtnant i FSB. Men måske er udnævnelsen udtryk for, at Putin nu kræver gennemgribende reformer i de væbnede styrker.

\section{Litteratur}

Baev, Pavel K. (1996). The Russian Army in a Time of Troubles, London: Sage Publications. Faurby, Ib (1996). "Militarets rolle i det russiske samfund", pp. 79-113 i Märta-Lisa Magnusson (red.), Rusland - et âbent samfund?, Esbjerg: Sydjysk Universitetsforlag.

Faurby, Ib and Märta-Lisa Magnusson (1999). "The Battle(s) for Grozny", Baltic Defence Review, No. 2, pp. 75-87.

Faurby, Ib og Märta-Lisa Magnusson (2000). "Europarådet, Rusland og krigene i Tjetjenien", Udenrigs, nr. 2, pp. 39-51.

Holmberg, Joakim (2000). "Den ryska marinen - en studie i sönderfal", Kungl Krigsvetenskapsakademiens Handlingar och Tidskrift, 3. häfte, pp. 99-123.

Magnusson. Märta-Lisa og Ib Faurby (1999). "Endlösung i Tjetjenien?". Udenrigs, nr. 4. pp. $39-52$.

Magnusson, Märta-Lisa og Ib Faurby (2000). "Hvorfor ville russerne krig? Mediernes rolle under de to russisk-tjetjenske krige", Nordisk ostforum. nr. 3, pp. 31-46.

Main. S.J. (2000). "North Caucasus Military District: Defending Russia's Interests in the Caucasus", pp. 38-64 in A.C. Aldis (ed.), The Second Chechen War, Sandhurst: Conflict Studies Research Centre.

Moller. Karsten (2000a). "Ruslands nye nationale sikkerhedskoncept og militierdoktrin", Militurt Tidsskrift, nr. 4. pp. 349-378.

Moller, Karsten (2000b). "Putins Rusland", Militart Tidsskrift, nr. 4. pp. 347-358.

Nilsson. Per Olov (1997), "Om den ryska militärreformen". Kungl Krigsvetenskapsakademiens Handlingar och Tidskrift, 1. häfte, pp. 77-136. 
var imidlertid, som nævnt. stodt på modstand fra generalstabschefen. general Kvasnin. Hvordan den nye forsvarsminister, Sergej Ivanov, vil stille sig til dette sporgsmål, vides endnu ikke.

Men Putin har klart tilkendegivet, at han onsker et starkt Rusland. Det betyder forst og fremmest en sterk centralmagt og en forbedret okonomi, men det betyder også effektive militere styrker. Dette er fremgået klart af mange udtalelser, blandt andet et mode med hojtstående officerer i januar 2001, hvor Putin påpegede sammenhiengen mellem en styrkelse af staten og moderniseringen af forsvaret. "Det er", sagde han, "nødvendigt at gøre hæren professionel, stærk, kompakt, disciplineret og mobil". De vabnede styrker må vaere i stand til at "udføre enhver tenkelig forsvarsopgave". Allerede i løbet af 2000 var der ifølge Putin truffet en rakke nøglebeslutninger, og man havde stået fast på "statens integritet for at sikre fred og orden, blandt andet i Nordkaukasus" (Krasnaja Zvezda, 19.01.2001).

Også $\mathrm{i}$ andre henseender er Putins vægt på forsvaret og hans egen tidligere tjeneste, FSB, kommet klart til udtryk. De fleste af de "generalguvernører", Putin har indsat til at overvåge republikker og regioner, kommer fra hæren eller FSB. Der er endvidere oprettet FSB-celler i det vabnede styrker og genindført før-militær uddannelse i skoler og uddannelsesinstitutioner (Møller, 2000b). Udnævnelsen i marts 2001 af Ivanov til "civil" forsvarsminister ændrer ikke ved dette billede $\mathrm{i}$ betragtning af hans fortid som generalløjtnant i FSB. Men måske er udnævnelsen udtryk for, at Putin nu kræver gennemgribende reformer i de væbnede styrker.

\section{Litteratur}

Baev, Pavel K. (1996). The Russian Army in a Time of Troubles, London: Sage Publications. Faurby, Ib (1996). "Militarets rolle i det russiske samfund", pp. 79-113 i Märta-Lisa Magnusson (red.), Rusland - et âbent samfund?, Esbjerg: Sydjysk Universitetsforlag.

Faurby, Ib and Märta-Lisa Magnusson (1999). "The Battle(s) for Grozny", Baltic Defence Review, No. 2, pp. 75-87.

Faurby, Ib og Märta-Lisa Magnusson (2000). "Europarådet, Rusland og krigene i Tjetjenien", Udenrigs, nr. 2, pp. 39-51.

Holmberg, Joakim (2000). "Den ryska marinen - en studie i sönderfal", Kungl Krigsvetenskapsakademiens Handlingar och Tidskrift, 3. häfte, pp. 99-123.

Magnusson. Märta-Lisa og Ib Faurby (1999). "Endlösung i Tjetjenien?". Udenrigs, nr. 4. pp. $39-52$.

Magnusson, Märta-Lisa og Ib Faurby (2000). "Hvorfor ville russerne krig? Mediernes rolle under de to russisk-tjetjenske krige", Nordisk ostforum. nr. 3, pp. 31-46.

Main. S.J. (2000). "North Caucasus Military District: Defending Russia's Interests in the Caucasus", pp. 38-64 in A.C. Aldis (ed.), The Second Chechen War, Sandhurst: Conflict Studies Research Centre.

Moller. Karsten (2000a). "Ruslands nye nationale sikkerhedskoncept og militierdoktrin", Militurt Tidsskrift, nr. 4. pp. 349-378.

Moller, Karsten (2000b). "Putins Rusland", Militart Tidsskrift, nr. 4. pp. 347-358.

Nilsson. Per Olov (1997), "Om den ryska militärreformen". Kungl Krigsvetenskapsakademiens Handlingar och Tidskrift, 1. häfte, pp. 77-136. 
Nilsson, Per Olov (1998). "Nya turer i den ryska militärreformen", Kungl Krigsvetenskapsakademiens Handlingar och Tidskrift, 1. häfte, pp. 69-93.

Nilsson, Per Olov (2000). "Rysslands militärdoktrin i början av 2000-talet", Kungl Krigsvetenskapsakademiens Handlingar och Tidskrift, 3. häfte, pp. 43-68.

Orr, Michael (2000). "Second Time Lucky?", Janes Defence Weekly, 8 March, pp. 32-36. Parchomenko. Walter (1999). "The State of Russia's Armed Forces and Military Reform". Parameters, Winter 1999-2000, pp. 98-110. 